This item was submitted to Loughborough's Research Repository by the author.

Items in Figshare are protected by copyright, with all rights reserved, unless otherwise indicated.

\title{
The timespace of identity and belonging: female migrants in Greece
}

\section{PLEASE CITE THE PUBLISHED VERSION}

https://doi.org/10.4337/9781786433237

\section{PUBLISHER}

Edward Elgar Publishing

\section{VERSION}

AM (Accepted Manuscript)

\section{PUBLISHER STATEMENT}

This is a draft chapter. The final version is available in Timespace and International Migration edited by Elizabeth Mavroudi, Ben Page and Anastasia Christou, published in 2017, Edward Elgar Publishing Ltd https://doi.org/10.4337/9781786433237. The material cannot be used for any other purpose without further permission of the publisher, and is for private use only.

\section{LICENCE}

All Rights Reserved

\section{REPOSITORY RECORD}

Mavroudi, Elizabeth. 2017. "The Timespace of Identity and Belonging: Female Migrants in Greece". Loughborough University. https://hdl.handle.net/2134/12932876.v1. 


\section{Chapter 9}

The timespace of identity and belonging: female migrants in Greece Elizabeth Mavroudi

\section{Introduction}

This chapter examines notions of migrant belonging by critically interrogating how women migrants from developed countries living in Athens, Greece adapt to dynamic lives and identities in Greece using the idea of timespace. The chapter seeks to examine how times and spaces have formed integral parts of their migration experiences in Greece. Using ongoing qualitative research in the form of in-depth interviews, the chapter discusses the challenges these women face in their lives and identities in Greece. Key to this chapter is the treatment of these women as complex, messy, living, feeling, thinking beings that resist categorization, representation and attempts to define how and when they belong. In particular, the chapter argues that perhaps it is through the daily and reflective thoughts and actions of these women that the linkages between timespace and migration can potentially be partially unravelled.

The chapter uses the experiences of first generation female migrants who moved to Greece for marriage, relationships and family reasons, and for the purposes of this chapter, the focus is on 34 women who have been in Athens for over ten years. Through the lens of timespace, I wish to complicate notions of migrant identity by exploring their sense of belonging as an integral part of their everyday lives, times, feelings, actions and spaces. By doing so, it becomes much harder to compartmentalize their lives and emotions, and separate out these different facets. However, this chapter argues that this is necessary in order to better comprehend the challenges and opportunities they face in Athens, Greece. Therefore, the chapter argues that it is important to ground these women's identities and belonging within the material timespace of their everyday lives.

The chapter will be organized through an examination of different moments in these women's lives and the ways in which their emotions and experiences are performed in timespace. By this I mean that time and space will be considered together in a holistic way when looking at specific experiences and feelings of belonging. The aim is therefore to discuss and unravel perceptions of belonging. Thinking through migration and timespace necessitates the intertwining of both and their enmeshing within the fabric of daily life, woven and animated through the stories, feelings and experiences of these women.

\section{Theorizing timespace and non-representational migrant belonging}

Migrant identities and senses of belonging can be seen as journeys over time and space, morphing and cross-cutting at different speeds and rhythms, juxtaposed between here and there in potentially fragmented, jarring, confusing but also multiple, hyphenated, fluid ways (Burdsey, 2006). For some scholars, migration is synonymous with movement and mobility; even as people settle for varying periods of time, migration is theorized as being a journey and migrants as being 'on the move' emotionally and symbolically if not always physically, and their resulting identities are seen as dynamic and malleable, as we see in the work of cultural theorists like Papastergiadis (2004), Clifford (1997) and Hall (1999), and geographers such as Dwyer (1999), Huang and Yeoh (2000), Blunt (2007), Hopkins et al. (2012) and Jöns et al. (2015). They are seen as non-essentialized, positioned, situated and grounded. As Hall (1999) points out, identities are not an essence but a dynamic positioning; the language he and other cultural theorists have used is useful for exploring identities and issues such as home, memory, performance and so forth in ways that allow representations to appear as partial and contested. 
If one argues that there isn't necessarily an end point to migration, our job as researchers is thus concerned with examining processes of identity formation, belonging and how migrants may resist national attempts to incorporate them by not fitting easily into their new homes. Viewing migrants and those in diaspora as potentially in-between here and there, past and present is helpful as it stresses their potential hybridity and the elusive nature of identity negotiation (Mavroudi, 2007a; 2007b). Such unfinished identities also remind us of the emotional and experiential aspect of living and feeling as a migrant (Christou, 2011), whereby memories emerge and become tangled with 'reality', culminating in perceptions which mix fact and fiction, here and there, past and present. Therefore, it is inevitable that this chapter deals with such perceptions, reminiscences, moments, performances, senses and constructions of self, identity, place, space and time. Rather than separate them out, this chapter, in line with the vision for the whole book, tries to focus on the whole-ness of people's lives and identities through their narratives and life-stories.

Although transnational migration and diaspora analyses complicate the idea of defined identities, traditional assimilation and integration, they also sometimes gloss over the complexity of timespace when considering identity, belonging and everyday life in a new context. This is because of fixations with here and/or there, past/present, and the separation of time and space rather than considering them together. Combining time and space might portray lives and identities in messier, more unpredictable and more emotionally relevant ways, which are harder to define and to pin down. Therefore, viewing and analysing migrant identity and belonging through the lens of timespace as this chapter attempts to do, can potentially loosen the 'boxes' put around time and space, and the ways in which they are categorized, ordered, structured and organized. A more flexible approach privileges the active: doing, feeling, acting, experiencing and in doing so has much in common with non-representational geographies and ways of thinking.

Geographers are interested in how places, lives and identities are constructed and represented in different ways and in different spaces. For some geographers, however, representation is no longer an adequate way to explore the intricacies and dynamics of complex everyday life and practices, which they feel are beyond generalization, control and quantification. For authors such as Thrift and Dewsbury (2002), representation is associated with 'dead geographies'. Their response to this is to stress the importance of everyday moments and performances in which times, spaces and places are not isolated and closed but open-ended and connected to, for example, institutions, nature, emotions and people. Geographers in this tradition have, therefore, attempted to explore notions of performance, rhythm, connection and movement as opposed to geographies of representation (Anderson and Harrison, 2016; Harrison, 2000; Crang, 2001; Nash, 2000; Thrift, 2008). If one follows the logic of Thrift and others, the act of performance in everyday life is one that is elusive, and that slips between dichotomies, resisting attempts to define what exactly is being represented. There is, therefore, no 'master plan', or way in which what is being portrayed can be controlled in non-representational theory, which is the most common way geographers engage with notions of performance. As Lorimer (2007, p.90) stresses, for Thrift 'the non-representational project is entirely...unmappable'. Such geographers are very much concerned with the 'doing' in everyday life, the actual practices that constitute continuous moments of performance; as Lorimer (2007, p.96) points out, " "becoming" seems to better cope with the continuance and mobility of "being" '. Thus everyday life is constantly 'becoming': 'Time and space cease to be simply containers of action. These ...offer a sense of space-time as Becoming, a sense of temporality as action, as performance and practice' (Crang 2001, p. 187). However, there has been a tendency towards 'presentism' (Jones, 2011) where the past and memories have been neglected. According to Jones, we need the 'complex ecologies of memory (and forgetting) which interlink through individual practicing bodies, texts, materialities, past/present/future timespaces to make the present time deep/complex rather than flat/pure' (Jones, 2011, p.875).

Geographers concerned with non-representation theory not only look beyond simplistic representations of performance, they also stress the importance of what Crouch (2003), for example, amongst others, has called 'spacing', or the use of the word 'space' as a verb rather than a 
noun. To 'space' is to be, to become and to participate in a world that is enacted and unfolding around oneself in a messy, hybrid mixture of us/them, human/unhuman, here/there - an in-between space that is difficult to pin down let alone quantify. The 'in-between' is therefore a problematic, but also an enigmatic and potentially liberating space. Its spacing is one that is almost unknowable, ambivalent and unexplainable, yet exists, for many, in the realms of creative imagination and performance. It is such an approach that this chapter argues can be useful in our analysis of migrant identities and belonging. Timespace as a concept and an approach to research and analysis of such identities thus disrupts the idea(l) that there are specific ways to be and feel whilst 'on the move' and rallies against any attempts to categorize and structure this belonging.

\section{Context and methods}

Greece has gone from being a country of emigration to a country of immigration (King et al., 1997; Cavounidis, 2002) and this has created challenges for its sense of national identity and citizenship, which is seen as linked to blood. Scholars have highlighted the fact that it is hard for immigrants to negotiate belonging as they have been Othered because there is significant racism and xenophobia (Triandafyllidou, 2001). There have also been debates on belonging, identity and incorporation and the ways in which these might occur (Hadziprokopiou, 2003; losifidis et al., 2007). Such approaches are important in attempts to define and account for migrant incorporation and the barriers to, and ways to promote, belonging and inadvertently focus on the passing of time as a process. Other work such as that by Naoussia and Lyons (2009) focuses explicitly on urban spaces of belonging and migrant interaction, which is equally valid. However, arguably, a more nuanced approach is needed to interrogate the detailed, complex and intricate ways migrants negotiate their identities in relation to both time and space (see, for example, Christou and Michail, 2015; Michail and Christou, 2016).

There are diverse migrant groups in Greece. One such group are migrants from other developed countries such as the UK. Some are 'expats' who live in Greece for temporary periods, but others do not fall so easily into this expat category even though they are from developed countries and may initially have moved to Greece on a temporary basis. In this latter group, many are women who came to Greece for a holiday or work then married Greeks, or to continue a relationships with a Greek man and then ended up staying. Hellum (1998) has outlined how foreign women married to Greeks on islands go from being tourists to foreign wives, and that this creates complex negotiation strategies and emotions.

Research on this group of women has highlighted how such marriages and relationships can help these women find paths to acceptance within Greek society (Lauth Bacas, 2002). However, my research challenges this and I want to examine how timespace can help us to make sense of being such a migrant in Athens. Rather than explain the processes and realities of their migrant lives and identities in definite and precise ways, I argue that we need to explore their lives and identities through and within timespace. This can allow us to analyse their voices, feelings and experiences in more holistic, subtle, flexible ways in which time and space are considered simultaneously. This might at first appear to be a more 'messy', disorganized, non-linear approach but hopefully it is more reflective of the ways in which migrants negotiate time and space in their lives and identities, using a full range of emotions and senses.

Perhaps unsurprisingly, the research on which this chapter is based is qualitative and explorative rather than representative. The women's voices and stories which appear are, out of necessity, snapshots into their lives, experiences and identities. The chapter is not attempting to draw generalized conclusions on these women or to come to an assessment of how they collectively feel, act or belong. This chapter focuses on one group of women who form part of a wider, ongoing, qualitative research project, which began in 2010, on people from developed countries living in Greece. The research this chapter is based on involved lengthy in-depth interviews carried out at participants' homes in Athens. All the interviews used in this chapter were conducted between 2010 and 2011, and lasted at least an hour (many lasted more). My positionality was a factor that was 
hard to ignore as my own mother's circumstances were similar to those of the women being spoken to. This meant that women were more likely to open up and share their experiences with me, and also that I reflected on my own upbringing and my mother's experiences with them. In many ways, this research is a personal project that connects me with my family's timespaces and with those of the women I interviewed.

Whilst not wishing to gloss over individual differences and positionalities, there are certain themes and issues that seem to ring true for, and connect, the majority of women spoken to, regardless of factors such as class, educational background and country of origin and which provide some background to what is discussed in this chapter. This research has revealed that many women remembered their initial move and early years in Athens as difficult. Most had not chosen to move to Greece and many did not feel their stay would be long-term. The vast majority had jobs and an independent lifestyle before they came to Greece and their new lives proved challenging. Most reflected on their decision to move as an uncertain and difficult one, one which they perhaps fell into, or did out of loyalty to their partner. These circumstances of migration, as a Greek man's wife then had repercussions more immediately on their ability to build relationships away from their husband's family, and more long-term as they struggled to make sense of their role and purpose in Greece, apart from their domestic one, and their changing identities. Most became mothers and home-makers in their early years of living in Greece. A couple managed to find new jobs and working careers, but for most this was hard to do after being out of the labour market for many years in a foreign country where they often did not speak the language very well. Most therefore became dependent on their husbands for their income and when relationships fell apart it left women with very little financial security. A further note is that although at first glance these women might appear to be migrants, this is not clear-cut as most did not perceive themselves as such, which reminds us of the arbitrary nature of categorization and the ambivalent ways people define themselves and their identities.

\section{Performing identity and belonging through timespace}

Non-representative approaches to viewing migrant lives and identities stress the need for performative, emotional and sensual analyses, which might be able to yield and partially unravel aspects of such lives that might otherwise be missed, or which are hidden or glossed over in attempts to categorize and define. This section explores how timespace analysis as an example of such a non-representative approach might help us to view migration as a performative role in which migrants enact being a different person, playing a role, as they negotiate past, present and future as well as space and time in linked ways. In doing so, for the women in this research, there seemed to be a tension between their need to objectify and pin down time and space and the reality of their messy, jumbled up timespace. In other words, there is a potential disjuncture between what is/has really happened versus the stories and narratives they tell. A timespace approach highlights this, partially reveals broken links, non-linear memories, and their attempts to capture and pigeon-hole the past, their identity, their experiences into 'acceptable' narratives that neatly follow the contours of time and space, when in reality, what occurs is the jarring juxtaposition of time and space in migrant lives. We can see this in the quote below, where Valerie compartmentalizes time into discrete entities, to try and make it more palatable to her, as a coping mechanism:

And so I had initially said I would be happy to move, I would make the commitment to move for five years and if after five years I didn't like it we were moving back. And also the part of the agreement was that every summer we spend two months in the States....And now all of my American friends are totally jealous because they say, you know, how did you get your husband to agree with that, I said I knew what was involved ... to back up a little bit, my father [worked abroad], so l'd moved around, I mean I knew to move somewhere for a year or two is not really giving a place a 
chance.... Because really I think five years is enough of a time to see if you can build a life somewhere, and if it's less than that, you really haven't had a chance to and also if you're miserable after five years you should probably get out of there because there's something that doesn't really work for you. (Valerie, from the US, living in Greece for ten years)

In reality, she talks later on in the interview about the need for flexibility, and 'letting go' of time in Greece, acknowledging how her life is developing in Athens as a constant process, which is dynamic and sometimes hard to handle and compress into manageable chunks. Her childhood which involved being on the move with parents, and her past successful career jostled for space and time as she spoke of the challenges and opportunities of living in Athens. It did occasionally seem hard for her to separate here and there, past and present and they appeared side by side as she spoke, as she made sense of her changing identity and need for adaptability.

Reflecting on the past, on for example, their feelings and actions when they first arrived as they tried to make sense of their lives is a good way to demonstrate how these women negotiate timespace and how it cross-cuts/rubs against more rational attempts to impose order on time and space. Here, this woman from New Zealand expresses the confusion, contradictions and emotions of moving. Time and space are portrayed as standing still, as a way for her to try and understand and explain why she did and acted the way she did:

I became rather child-like because I was now in a country where I didn't speak the language where my husband undertook to take care of everything, it was a kind of cocoon, protected environment where I was child-like and seen as child-like because I couldn't be myself or articulate myself as I would be in my own setting... ... many women said that they came for a relationship but I would always hold that people came for more reasons, you are also attracted by what that relationship can offer you, the context, the setting, I don't know what I thought, for a whole year with a new born baby I didn't ask for a washing machine, I thought this was Greece, I can't be too demanding so who was I? Who was this 30 year old who was prepared to boil nappies on a stove? (Hannah, from New Zealand, living in Greece for thirty years)

When reflecting on the past, in answering my questions, these women seemed to struggle with time and space, as they attempted to clarify, objectify time and space, and deal 'objectively' and 'rationally' with issues such as how long does it take to settle in, to speak the language, to feel at home, to compare now and then, in ways which 'closed in' time and space. It seems that perhaps we, as researchers, asking the questions we do of migrants, might be missing the point and in doing so are forcing migrants to put pressure on themselves to categorize and deal with time and space in arbitrary ways that do not help them make sense of their lives and identities. Therefore, we might need to re-think how we interview migrants and the type of research we do.

Responses on language demonstrate well the need for women to account for how long it took them to speak the language, and how they perform linguistically in different spaces compared to others. The following extract from Anne, a Welsh woman, demonstrates how others problematize her lack of language learning over time and the issues this creates in particular spaces. She feels the need to justify her lack of language skills and constructs a narrative which does so, in which she has diminished the importance of timespace because she does not want her lack of Greek to be a problem for her. This might be empowering for her and a way to deal with her situation yet it shows that timespace is malleable and that the act of remembering is an excellent example of our ability to manipulate time and space in order to construct particular narratives. Yet she has outwardly compartmentalized time and space into then and now as a way to explain her (lack of) language skills: 
I speak Greek badly, I have what I call supermarket Greek so I can go out there and cope but don't ask me to discuss politics because I can't and I can't follow the news, it's horrendous. I had some lessons at the beginning but I decided that, well I'm not stupid, but I decided that I'm one of those people who are not very good at languages. I'm ok about it, I'm not depressed about it. My husband has huge issues about it, he always feels we have to go out in company and speak English because he says you sit in the corner and don't contribute at all and he hates translating so we have issues and his favourite saying is you know, the cleaner, she's only been here a year and she speaks perfect Greek and you don't, well you know, so if I'm completely honest there's more things I'd rather do than study a language. Tell you what, if I tried to speak Greek out there, $70 \%$ of the time they'll talk back in English because they want to practice. (Anne, from Wales, living in Greece for twenty years)

When it came to discussing belonging, for many women, it seemed that questions on home, belonging and identity were the hardest to answer, and provoked some very emotional responses. The majority of women felt somehow in-between their country of origin and Greece. Many returned as often as they could to see friends and relatives and were attached to them, and to their homelands. Feeling confusion between here and there, past and present was common as timespace served to highlight the difficulties of living and feeling in-between. For them, their timespace was hard to deal with; as they tried to discuss identity in concrete, rational terms, it became clear that this complicated timespace, was stretching and connecting (but also disconnecting) different worlds and seemed to epitomize their ambivalent sense of belonging and made their performative and multiple roles as 'mother', 'foreigner, 'expat' and so forth challenging. In other words, negotiating timespace was often not easy for them to do as these two extracts reveal:

I: Where do you feel you belong?

R: Oh, nowhere, nowhere. I'm a foreigner in England now even though I love it when I go back, even though I was desperate to leave, I feel more confident when I'm in England... [but] in a way I belong here - this is my home and my work, in a way I belong here more than I belong in the UK (Katie, from England, living in Greece for thirty years)

At the (Greek) school [her children attended] sometimes I did feel that there were some people who weren't comfortable with me being a foreigner but we as two of the foreign mothers were left out of quite a few things, there were quite a few incidents and maybe I was less secure, I have never regained the self-confidence that I had in my home country (Donna, from New Zealand, living in Greece for fifteen years)

Their identities and senses of belonging were complex, confused, and often ambivalent; they were not easy to pin down and articulate. Timespace analysis of these women's lives and identities demonstrates that both time and space coalesce in uneasy, potentially difficult ways as they search for belonging, becoming Othered, and excluded as they deal with their dislocation:

I feel I am treated as a foreigner because I look different, I'm not treated as a foreigner in Wales so if I had to be cornered on it I would say my home is in Wales... I would say the first ten years my home was definitely Wales and I was quite depressed here, I always longed to be there, and because the children were in school I didn't have the freedom to go whenever I wanted, but this latter five years I find I enjoy it here much more and if I'm up there a long time, I'm really eager to come back but being here, come the time to go back, I'll be quite eager to go there, I'm like 
a gypsy, I don't feel I have roots anywhere, I'm in-between. (Anne, from Wales, living in Greece for twenty years)

For this Welsh woman, time and space have become both a barrier and a source of happiness in her life as she has struggled to deal with living and feeling here and there. This has culminated in an inbetween-ness in which time and space are juxtaposed, and operate both together and out of sync as she finds she belongs both here and there, and ultimately nowhere. It is as if timespace comes together to help her to feel belonging but at other moments it is disrupted and she struggles with her identity.

For others, such as Lydia from Scotland there are even stronger emotions associated with disruption, dislocation and sadness and there is also confusion over timespace, which she finds hard to deal with because of mixture of events that have occurred in her life:
R: I think maybe it's, it's got a lot to do with the different times in my life maybe, if I've been unhappy here because you know I went through a divorce and I had problems there, maybe then I was not happy here and I felt a bit unsettled. There were other times when I think, oh I'm so lucky to be living in this country! [laughs] So it's, that's never been a sort of permanent ...... stable, yeah, sort of thought in my mind that's changed over the years.
I: Depending on your personal kind of circumstances?
$R$ : Yeah, sometimes when I'm here I think, oh I wish I was back in Scotland and then when I go back to Scotland I think, oh how many more days is it before I get back to Greece! (Lydia, from Scotland, living in Greece for 37 years)

For her, timespace is ruptured, uneasy, hard to get a grip on: performing and negotiating her belonging and identity is a constant mixture, a flurry of events, emotions, times and spaces coexisting and jostling for attention. Analysing timespace allows us to focus more explicitly on how time and space merge within such complex lives and identities, and in particular, how they themselves deal with time and space as they face challenges and opportunities.

\section{Concluding thoughts}

This chapter has argued that trying to analyse identity and belonging in the context of migration is helped by an approach which is sensitive to timespace in non-representational ways: in other words, it has focused on the interplay of how time and space are negotiated in people's minds, experiences, performances and narratives. Although migrants may try to pin down time and space, and manage it, in order to try to feel at home, and to deal with life, for many in this piece of research, this attempt was often elusive and challenging.

This chapter has suggested that rather than remembering and dealing with the past in a linear, objective and orderly way, timespace impacts upon their lives and identities in disjointed, messy and ambivalent ways. This stresses the need for geographers and other social scientists to look more closely at the relationships between timespace, migration, and identity, particularly for more hidden groups, and particularly in the light of the continued physical and virtual relationships migrants, and future generations, have with their homelands.

Timespace analysis privileges the immediacy and relevance of emotions and senses emerging as time and space converge, or are torn apart as people live, remember, experience and perform roles within their daily lives. A non-representational timespace approach to migrant identity and belonging stresses the need to let these emotions and senses surface in their own way. It highlights that they are positioned and grounded within the everyday, and the messy ways in which 
time and space appear, and are made sense of, within such lives, rather than try and explain, rationalize, categorize and account for time and space in separate, discrete ways.

To analyse migrant lives and identities through the lens of timespace necessitates an approach which allows people to discuss and perform their feelings of belonging freely, and in different ways, as an integral aspect of research design. In doing so, we need to do more research which pays explicit attention to timespace through the use of research methodologies which allow us to trace the impacts of timespace more clearly (such as life stories, repeat interviews, and longitudinal research). Migrant lives and identities may be theorized as mobile and dynamic journeys; however, we also need to pay attention to the challenges and opportunities created by timespace.

\section{References}

Anderson, B. and P. Harrison (eds) (2016), Taking-Place: Non-Representational Theories and Geography, New York and London: Routledge.

Burdsey, D. (2006), ' "If I ever play football, Dad, can I play for England or India” British Asians, sport and diasporic national identities', Sociology, 40, 11-28.

Blunt, A. (2007), 'Cultural geographies of migration: mobility, transnationality and diaspora', Progress in Human Geography 31, 684-694.

Cavounidis, J. (2002), 'Migration in southern Europe and the case of Greece', International Migration, 40(1), 45-70.

Christou, A. and D. Michail (2015), 'Migrating Motherhood and Gendering Exile: Eastern European Women Narrate Migrancy and Homing', Women's Studies International Forum, http://dx.doi.org/10.1016/j.wsif.2015.06.005

Christou, A. (2011), 'Narrating lives in (e)motion: Embodiment, belongingness and displacement in diasporic spaces of home and return', Emotion, Space and Society 4, 249-257.

Clifford J. (1997), Routes: Travel and Translation in the Late Twentieth Century, Cambridge MA: Harvard University Press.

Crang, M. (2001), 'Rhythms of the city : temporalised space and motion.', in J. May and N. Thift (eds), Timespace : geographies of temporality, London: Routledge, pp. 187-207.

Crouch, D. (2003), 'Spacing, performing and becoming: Tangles in the mundane', Environment and Planning A, 35, 1945-1960.

Dwyer, C. (1999), 'Contradictions of community: Questions of identity for young

British Muslim women', Environment and Planning A, 31, 53-68.

Hadziprokopiou, P. (2003), 'Albanian immigrants in Thessaloniki, Greece: Processes of social and economic incorporation', Journal of Ethnic and Migration Studies, 29 (6), 1033-57.

Hall, S. (1999), 'Cultural identity and diaspora', in S. Vertovec and R. Cohen (eds), Migration, Diasporas and Transnationalism, Cheltenham: Elgar, pp.299-314.

Harrison, P. (2000), 'Making sense: embodiment and the sensibilities of the everyday', Environment and Planning D: Society and Space, 18, 497-517.

Hellum, M. (1998), Foreign Wives in the wake of tourism. Creating identity on an island in the Greek archipelago, Mannheimer Zentrum für Europäische Sozialforschung (MZES), Mannheim, Arbeitspapiere Arbeitsbereich I / Nr. 31, accessed 15 November 2016 at http://www.mzes.unimannheim.de/publications/wp/wp1-31.pdf

Hopkins, P., M. Kwan and C. Aitchison (2012), Geographies of Muslim Identities: Diaspora, Gender and Belonging, London: Ashgate.

losifidis, T., M. Lavrentiadou, E. Petracou and A. Kontis (2007), 'Forms of social capital and the incorporation of Albanian immigrants in Greece', Journal of Ethnic and Migration Studies, 33 (8), $1343-1361$.

Jones, O. (2011), 'Geography, memory and non-representational geographies', Geography Compass, 5, 875-885. 
Jöns, H., E. Mavroudi and M. Heffernan (2015), 'Mobilising the elective diaspora: German-American academic exchanges in the postwar period', Transactions of the Institute of British Geographers, 40, 113-127.

King R., A. Fielding and R. Black (1997), 'The international migration turnaround in Southern Europe', in R. King and R. Black (eds), Southern Europe and the new immigrations, Brighton: Sussex Academic Press, pp.1-25.

Lauth Bacas, J. (2002), 'Cross-border marriages and the formation of Transnational. Families: A case study of Greek-German couples in Athens', WPTC-02-10, accessed 27 November 2016 at http://www.transcomm.ox.ac.uk/working\%20papers/WPTC-02-10\%20Bacas.pdf.

Lorimer, H. (2007), 'Cultural geography: worldy shapes, differently arranged', Progress in Human Geography, 31 (1) 89-100.

Mavroudi, E. (2007a), 'Diaspora as process: (de)constructing boundaries', Geography Compass, 1 (3), 467-479.

Mavroudi, E. (2007b), 'Learning to be Palestinian in Athens: constructing diasporic national identities' Global Networks, 7(4), 392-412.

Michail, D. and A. Christou (2016), 'Diasporic youth identities of uncertainty and hope: Second generation Albanian experiences of transnational mobility in an era of economic crisis in Greece', Journal of Youth Studies, DOI: 10.1080/13676261.2015.1136052

Nash, C. (2000), 'Performativity in practice: some recent work in cultural geography', Progress in Human Geography, 24(4), 653-664.

Noussia, A. and M. Lyons (2009), 'Inhabiting spaces of liminality: Migrants in Omonia, Athens', Journal of Ethnic and Migration Studies, 35(4), 601-624.

Thrift, N. (2008), Non-Representational Theory: Space, Politics, Affect, New York and London: Routledge.

Thrift, $\mathrm{N}$ and J-D. Dewsbury (2000), 'Dead geographies and how to make them live', Environment and Planning D: Society and Space, 18, 411-432.

Triandafyllidou, A. (1998), 'National identity and the 'Other', Ethnic and Racial Studies 21(4), 593612.

Yeoh, B. and S. Huang (2000), 'Home and away: foreign domestic workers and negotiations of diasporic identity in Singapore', Women's Studies International Forum 4, 413-29. 